\title{
Systemic Discrimination in Policing: Four Key Factors to Address
}

\author{
Rajnish R. Saini*
}

\begin{abstract}
Canada's demographic landscape is comprised of a breadth of cultures and religious beliefs, racialized groups, Indigenous persons, and genders and sexual orientations. In contrast, the demographic composition of many police services in Canada does not reflect the communities they serve. While efforts of police services across Canada to diversify have led to a proliferation of racial minorities, women, and Indigenous persons gaining employment within police organizations, serious obstacles of exclusion, racism, and discrimination remain. This paper will critically analyze four factors that accentuate and contribute to systemic discrimination in policing and provide recommendations to identify, mitigate, and address this issue.
\end{abstract}

Key Words Police; racism; exclusion; diversity; occupational segregation.

\section{SYSTEMIC DISCRIMINATION IN POLICING}

The demographic composition of many police services in Canada, traditionally comprised of Caucasian males, does not reflect the communities they serve (Jain et al., 2000). Recent diversity efforts have culminated in a significant number and percentage of police services hiring women, Indigenous persons, and members of racialized and cultural minority groups (Niemi, 2004; Jain et al., 2000). However, well-established concepts rooted in our colonial history, integrated into our legislation, maintained in our institutional practices, and enabled in our organizational culture create serious barriers of exclusion, racism, and discrimination amongst police services in Canada (Sloly, 2020). This paper will critically analyze four factors that accentuate and contribute to systemic discrimination in policing: (1) diversity concentrated at the constabulary level, (2) occupational segregation, (3) racial harassment, and (4) supervisor evaluation. Furthermore, recommendations will be provided to identify, mitigate, and address systemic discrimination in policing.

Canada's demographic landscape is comprised of a breadth of cultures and religious beliefs, racialized groups, Indigenous persons, and genders and sexual orientations (Szeto, 2014). As a result, police services attempt to diversify in response to the changing social milieu by implementing internal policies and creating government initiatives such as the Employment Equity Act, 1995 (Szeto, 2014). For instance, in 1988, a Sikh Indo-Canadian named Baltej Singh Dhillon applied to the Royal Canadian Mounted Police (RCMP) as a police constable and was denied because the dress code forbade beards and the wearing of turbans in place of the uniform hat (Baker, 2019). Dhillon appealed the decision to the RCMP Commissioner, who in turn made a recommendation to the federal government to remove the banning of beards and turbans in the interest of diversification (Baker, 2019). This proposed reform incited acrimony across Canada, as over 90,000 Canadians signed petitions against allowing turbans to be worn in the RCMP, while certain businesses profited by promoting anti-turban pins (Figure 1) or calendars satirizing uniform changes (CBC, 2017; Baker, 2019). Even after becoming a full-time RCMP member once the dresscode changes were announced by the government, Dhillon received death threats from the public and was ostracized within the police service (CBC, 2017; Baker, 2019). To illustrate the systemic discriminatory practices of police services, the exemption for hijabs was not implemented in the RCMP until 2016 (CBC, 2017). These systemic discriminatory practices are evidently still espoused in the Brantford Police Service, which has no policy to address turbans or any accommodation for members' religious observances.

While diversification efforts of police services across Canada have led to a proliferation of racial minorities, women, and Indigenous persons gaining employment within police

Correspondence to: Rajnish R. Saini, School of Graduate Studies, Wilfrid Laurier University, 23 Webb Avenue, Brantford, ON N3T 6S5, Canada.
E-mail: rajsaini911@hotmail.com
To cite: Saini, R. R. (2021). Systemic discrimination in policing: Four key factors to address. Journal of Community Safety and Well-Being, 6(1), 11-16.
https://doi.org/10.35502/jcswb.179
(C) Author(s) 2021. Open Access. This work is distributed under the Creative Commons BY-NC-ND license. For commercial re-use, please contact sales@sgpublishing.ca.

gPUBLISHING Published by SG Publishing Inc. CSAA Official publication of the Community Safety Knowledge Alliance. 
organizations, serious obstacles of exclusion, racism, and discrimination remain (Szeto, 2014; Jain et al., 2000). The aforementioned barriers accentuate systemic discrimination, which is defined as "behavioural trends, policies or procedures that are part of the structures of an organization, and which create or perpetuate disadvantage for racialized persons" (Ontario Human Rights Commission, n.d, para. 2). The following four factors accentuate and contribute to systemic discrimination in policing: (1) diversity concentrated at the constabulary level, (2) occupational segregation, (3) racial harassment, and (4) supervisor evaluation (Niemi, 2004).

\section{DIVERSITY CONCENTRATED AT THE CONSTABULARY LEVEL}

Fundamentally, the Vertical Mosaic conveys that Canada is a mosaic of different races, ethnicities, languages, and religious groupings which are unequal in status and power (Helmes-Hayes, 2019). According to the Vertical Mosaic, those in elite positions exercise influence over all domains of society (Inwood, 1999). A racially vertical mosaic consisting of a "Caucasian male culture" exists in a plethora of police services despite two decades of employment equity (Jain et al., 2000, p. 68). This vertical mosaic is exemplified in many police services as recruitment and selection focus on hiring members with diverse backgrounds for entry-level police constable positions (Niemi, 2004).

Consequently, many police services are negligent in diversifying all organizational levels, including the civilian

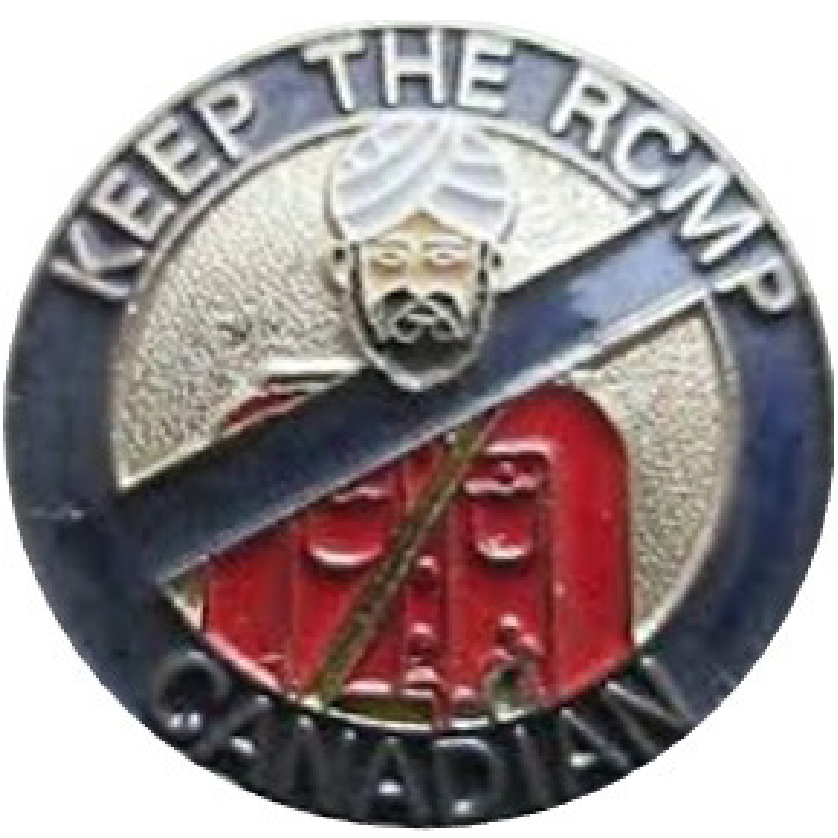

FIGURE 1 Keep the RCMP Canadian Pin Sold in 1989. This image of the pin was being sold to many Canadians when Baltej Singh Dhillon attempted to appeal his decision to become a member of the RCMP in 1989. Adapted from "Controversial Canada RCMP No Sikh Pin Keep Canadian Silver Coloured Backing" by Redmoongifts, 2020 (https:// www.ebay.com/itm/Controversial-Canada-RCMP-No-Sikh-Pin-KeepCanadian-Silver-coloured-backing-/193407724078). In the public domain. ranks. For instance, Ontario has 51 police services, and analysis reveals that there are 44 male Caucasian police chiefs, four female police chiefs, two police chiefs from racialized minority groups, and one police chief who identifies as an Indigenous person (Ministry of the Solicitor General, 2019; Ontario Association of Chiefs of Police, 2020) (Figure 2). This blatantly illustrates the racially vertical mosaic consisting of a "Caucasian male culture" in policing (Jain et al., 2000, p. 68).

The recent appointment of the Chief of Police for the newly created Surrey Police Service in British Columbia exacerbates the racially vertical mosaic that has been prevalent in policing for decades. The City of Surrey has a population base that is largely composed of racialized minority groups, and the appointment of a male Caucasian Police Chief may contribute to mistrust within the community (Stewart \& Azpiri, 2020; Statistics Canada, 2019a). This recent hiring indicates that the glass ceiling is thick for racialized police officers wishing to gain employment in senior management positions within policing (Stewart \& Azpiri, 2020).

\section{OCCUPATIONAL SEGREGATION}

In policing, women, racialized minority groups, and Indigenous persons are primarily concentrated at the constable level (Niemi, 2004; Conor et al., 2020). Efforts at diversification in policing often ignore career progression and promotional strategies, perpetuating occupational segregation (Rigaux, 2018). The low representation of women, racialized minority groups, and Indigenous persons in specialized units and high-ranking positions within the police service creates a climate that hinders professional mobility while promulgating the male Caucasian perspective (Jain et al., 2000). Furthermore, it fails to provide role models for young people from diverse groups within and outside the police organization (Canadian Centre for Diversity and Inclusion, 2019). An example of occupational segregation occurred in 2013, when Staff Sergeant Baljiwan Sandhu entered the promotional process for the rank of inspector with the Peel Regional Police Service. He was one of 33 applicants seeking promotion to the rank of inspector. Sandhu's cultural and linguistic skills resulted in his superiors routinely seconding him for assignments involving the South Asian community (Grewal \& Rankin, 2017). While these skills were

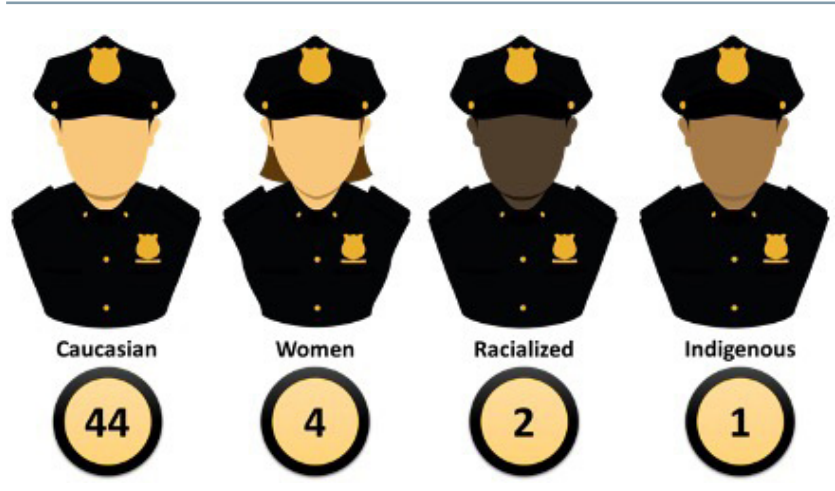

FIGURE 2 Demographics of Chiefs of Police in Ontario. This infographic illustrates the demographic composition of police chiefs in the province of Ontario for 51 police services. Created by Raj Saini, 2020. 
considered an asset to promote diversity, Sandhu was denied the promotion because, according to senior officers, he lacked the frontline supervisory experience to become an inspector (Grewal \& Rankin, 2017).

\section{RACIAL HARASSMENT}

Many police officers representing Indigenous persons and racialized minority groups experience implicitly or explicitly offensive jokes, insults, and other acts of degradation (Rigaux, 2018; Bureau, 2019). Ontario Regulation 268/10 - Police Service Act of Ontario delineates a code of conduct that all police officers in Ontario must adhere to (Government of Ontario, 2018). In the code of conduct, all police officers are to "treat or protect persons equally without discrimination with respect to police services because of race, ancestry, place of origin, colour, ethnic origin, citizenship, creed, sex, sexual orientation, age, marital status, family status or disability" (Government of Ontario, 2018, p. 10). For fear of being alienated, ostracized, and committing so-called "career suicide," many minority group police officers simply disregard and tolerate racial harassment (Carpenter, 2020). Such was the case for Staff Sergeant Baljiwan Sandhu of Peel Regional Police Service and Inspector Baltej Singh Dhillon of the RCMP. They were subjected to racially derogatory comments and insults throughout their respective careers (Baker, 2019; Grewal \& Rankin, 2017).

Sandhu listed examples of alleged discrimination that he faced when he started his career. These included:

Officers mimicked his accent. "It reached the point where I felt like I was an ethnic punching bag, yet I soldiered on," he said in his complaint.

He once walked into a packed gym at police headquarters, and someone shouted: "Hey, no one called a cab!" Sandhu said the room "erupted with laughter," which he found distressing but "forced" himself to "laugh" and to "endure" the "blatant racial slur." (Mall, 2017, para. 5-7)

\section{SUPERVISOR EVALUATION}

The traditional performance appraisal method creates obstacles for the professional mobility of women, Indigenous persons, and racialized minority police officers (Oliver, 2017). The prerequisite of positive assessment or approval from one's supervisor becomes one of the most formidable barriers to equal representation in police services' upper echelons (Niemi, 2004). A Caucasian male perspective may often operate at the exclusion of police officers who are women, Indigenous persons, and members of racialized minority groups (Jain et al., 2000). A supervisor's opinion about a candidate for promotion can be fraught with arbitrariness and racial bias (Niemi, 2004). An example of this occurred in the Ottawa Police Service, when Inspector Samir Bhatnagar entered the promotional process in 2012 for the rank of Superintendent. He successfully entered the candidate pool, scoring the highest mark, but was overlooked for promotion. Ultimately, the chief, deputy police chiefs, and civilian director decide who is promoted, based on several factors that include "trust, ability to support the executive, fit, and needs of the organization" (Yogaretnam, 2018, para. 15). Bhatnagar alleges he was denied a promotion because the Chief of Police and members of the senior executive subjected him to differential and disproportionate treatment because he was a "brown-skinned man of East Indian origin" (Yogaretnam, 2018, para. 4).

Despite all the rhetoric of inclusion and recruitment from visible minority communities, the Ottawa Police Service does not have a single officer of colour at the rank of Superintendent or above, and there has only been one in the entire 150-year history of the service. (Yogaretnam, 2018, para. 5)

Since Inspector Samir Bhatnagar's complaint to the Human Rights Tribunal in 2017, the Ottawa Police Service named Peter Sloly as the new Chief of Police in October of 2019 and Uday Jaswal as Deputy Chief of Police in September of 2018, both of whom represent racialized groups (Ottawa Police Service, 2021; Britneff, 2018).

\section{RECOMMENDATIONS}

This section discusses recommendations to mitigate and manage factors that contribute to systemic discrimination in policing. Assessing and tackling systemic discrimination can be complex. One of the first steps is that police services need to be aware that the current methods and practices adversely affect women, racialized groups, and Indigenous persons (Ontario Human Rights Commission, n.d.). The following three factors can be used to identify, mitigate, and address systemic discrimination in policing: (1) policies, practices, and decision-making processes, (2) statistical data, and (3) organizational culture (Ontario Human Rights Commission, n.d.).

\section{Policies, Practices, and Decision-Making Processes}

Policies, practices, and decision-making processes within police organizations can create serious barriers of exclusion, racism, and discrimination for women, Indigenous persons, and racialized minority police officers (Ontario Human Rights Commission, n.d.). In most circumstances, the design and implementation of policies, practices, and decisionmaking processes do not account for individual differences and are based on the dominant culture, which is the male Caucasian perspective, as the norm (Ontario Human Rights Commission, n.d.). This was epitomized in a recent incident where the RCMP reassigned several frontline Sikh and Muslim officers who had unshorn facial hair for religious reasons (CBC News, 2020). During the COVID-19 pandemic, RCMP policy required officers to be clean-shaven to ensure a proper fit of N95 respirators (CBC News, 2020). The use of the dominant culture as the norm is reflected in the design and implementation of this policy, practice, and decision-making process. To eliminate subjective considerations, differing standards and biases, police services need to include women, Indigenous persons, and members of racialized minority groups in the decision-making processes for designing and implementing policies and practices.

\section{Statistical Data}

Collecting and analyzing statistical data can provide police services information regarding the management of women, 
Indigenous persons, and racialized minority groups within the police service (Ontario Human Rights Commission, n.d.; Sloly, 2020). The use of disaggregated data can illustrate the representation of women, Indigenous persons, and members of racialized groups within a police service and those in positions of leadership (Ontario Human Rights Commission, n.d.; Sloly, 2020).

For instance, nationally, four percent of police officers identify as Indigenous persons, while eight percent of police officers identify as belonging to a visible minority group, and women account for twenty-two percent of all police officers (Conor et al., 2020). However, in the Brantford Police Service (Figure 3), four percent of officers identify as Indigenous persons, while five percent of officers identify belonging to a racialized minority group, and women account for sixteen percent of all police officers (Brantford Police, 2020). Based on this data, the Brantford Police Service is well below the national average in hiring women and racialized minority groups for the role of police officer (Statistics Canada, 2019b). Statistical data can be used to assist in defining recruitment, selection, and promotion strategies to increase diversity within all regions and at all levels.

\section{Organizational Culture}

Organizational culture is conventionally defined as the "ensemble of beliefs, assumptions, values, norms, artifacts, symbols, actions, and language patterns shared by all members of an organization" (Huff, 2014, para. 1). The basic underlying assumptions of police organizational culture reflect a traditionalist, Caucasian male-dominated,

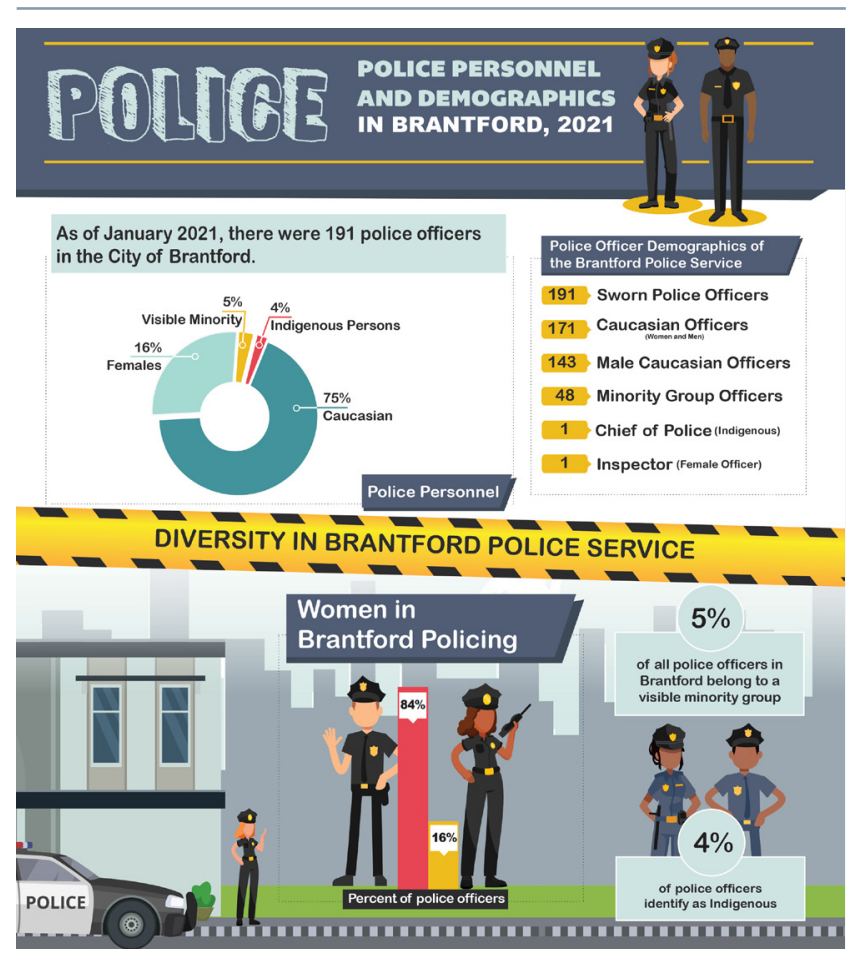

FIGURE 3 Demographics of Police Personnel in the Brantford Police Service, 2021. The infographic illustrates the demographics of police officers at the Brantford Police Service. Adapted from "January 2021 Brantford Police Service Sworn Roster," by Raj Saini 2021 paramilitary hierarchical structure governed by formal rules, regulations, procedures, and operational protocols (Batts et al., 2012). Forbidding beards and turbans in the RCMP and relegating Sikh and Muslim officers who have facial hair for religious reasons to administrative duties are examples of an organizational police culture that perpetuates systemic discrimination (Baker, 2019; CBC News, 2020). Despite the diversification of police services, aspects of the traditional police culture remain entrenched and can marginalize or alienate racialized persons (Ontario Human Rights Commission, n.d.).

Police services have to ensure that they do not unconsciously engage in systemic discrimination by using the dominant culture as the norm. This takes vigilance and a willingness to monitor and review statistical data, policies, practices and decision-making processes (Ontario Human Rights Commission, n.d.). For instance, the development of a promotional or interview panel that is diverse, reflecting differences of both gender and race, is a trifling implementation but can profoundly affect the organizational culture of a police service (Jain et al., 2000), bringing about positive change.

It has been found that when a person of one race interviews another person of the same race (a Caucasian person interviews another Caucasian person, or a [B]lack person interviews another [B] lack person, for example), they tend to assign higher ratings to those candidates who are from the same racial group. (Jain et al., 2000, p. 67)

Additionally, the promotion of women, Indigenous persons, and racialized groups to senior ranks within a police service can influence organizational culture. Conventionally, police organizational culture elicits conformity and assimilation (Szeto, 2014). Organizational diversity in a police service's senior ranks creates a deviation from the traditional, Caucasian male-dominated police culture (Jain et al., 2000). This, in turn, attenuates systemic discrimination within a police organization and allows for different policing perspectives to develop, promoting public trust and confidence (Jain et al., 2000).

\section{CONCLUSION}

Systemic discrimination results from deep-rooted obstacles that create serious barriers of exclusion, racism, and discrimination in policing. A vertical mosaic exists in policing consisting of a male Caucasian perspective that influences and dominates all facets of policing. While police services are proactively diversifying the constabulary level within their respective organizations, they are negligent about diversification strategies in the senior ranks. The opinion of a supervisor about a candidate for promotion can be fraught with arbitrariness and racial bias, which in turn creates occupational segregation for women, racialized minority groups, and Indigenous persons within police services. Furthermore, many police officers representing Indigenous persons, racialized minority groups, and women experience some form of harassment but choose to remain silent because they fear being alienated or ostracized, or having their career impeded. 
To identify, mitigate, and address systemic discrimination in policing, statistical data can be used to assist in defining recruitment, selection, and promotional strategies to increase diversity at all levels of the police service. Additionally, by including women, Indigenous persons, and members of racialized minority groups in the design and implementation of policies, practices, and decision-making processes, police services can eliminate subjective considerations, differing standards, and biases. Lastly, vigilance and a willingness to monitor and review statistical data, policies, practices, and decision-making processes within police services can change a traditional police organizational culture from one that marginalizes or alienates women, Indigenous persons, and members of racialized minority groups to one that is truly inclusive.

\section{CONFLICT OF INTEREST DISCLOSURES}

The author has no conflicts of interest to declare.

\section{AUTHOR AFFILIATIONS}

* School of Graduate Studies, Wilfrid Laurier University, Brantford, ON, Canada.

\section{REFERENCES}

Baker, R. (2019, August 1). As he readies for new role, 1st Mountie to wear turban reflects on RCMP career. https://www.cbc.ca/news/ canada/british-columbia/baltej-dhillon-1st-turban-wearing-rcmpofficer-retires-1.5233535

Batts, A. W., Smoot, S. M., \& Scrivner, E. M. (2012). Police leadership challenges in a changing world. Department of Justice, National Institute of Justice. https://www. publicsafety.gc.ca/lbrr/archives/ cnmcs-plcng/cn32559-eng.pdf

Brantford Police Service. (2021, January 04). January 2021 - Brantford Police Service Sworn Roster. https://pride.wrps.on.ca/admin/_la youts $/ 15 /$,Danalnfo=bpsintranet. prideinternal.ca+WopiFrame2. aspx? sourcedoc=/admin/Weekly\%20Schedules/Week\%20 Of\%20December\%2014.xlsx\&action=default

Britneff, B. (2018, August 1). Police services board names Uday Jaswal as new Ottawa deputy police chief. Global News. https://globalnews. ca/news/4364895/uday-jaswal-new-ottawa-deputy-police-chief/

Bureau, B. (2019, March 8). Black RCMP officers say they endured racism "on a regular basis." CBC News. https://www.cbc.ca/news/ politics/rcmp-anti-black-racism-1.5048850

Canadian Centre for Diversity and Inclusion. (2019, February 25). Current State Inclusivity Assessment - Prepared for the Peel Regional Police Services Board. https://www.peelpoliceboard.ca/en/boardmeetings/resources/Presentations/Peel-Police---Diversity-Equity-AuditReport---FINAL--.pdf

Carpenter, P. (2020, June 28). Black Montreal officers react to union's claim there is no systemic racism in the force. Global News. https:// globalnews.ca/news/7118921/black-montreal-police-system-racism/

CBC. (2017, May 11). The turban that rocked the RCMP: How Baltej Singh Dhillon challenged the RCMP-and won. CBC.ca. https://www. cbc.ca/2017/canadathestoryofus/the-turban-that-rocked-the-rcmphow-baltej-singh-dhillon-challenged-the-rcmp-and-won-1.4110271

CBC News. (2020, September 24). RCMP mask policy for bearded frontline officers must be rectified. CBC News. https://www.cbc.ca/ news/canada/british-columbia/rcmp-mask-beard-policy-1.5738207

Conor, P., Carrière, S., Amey, S., Marcellus, S., \& Sauvé, J. 12020, December 8). Police resources in Canada, 2019. Statistics Canada. https://www150.statcan.gc.ca/nl/pub/85-002-x/2020001/ article/00015-eng.htm
Grewal, S., \& Rankin, J. (2017, April 22). Peel police discriminated against decorated officer based on race, rights tribunal rules. The Star. https://www.thestar.com/news/gta/2017/04/22/peelpolice-discriminated-against-decorated-officer-based-on-race-rightstribunal-rules.html

Government of Ontario. (2018, November 19). Police Services Act - Ontario Regulation 268/10. https://www.ontario.ca/laws/ regulation/100268\#BK40

Helmes-Hayes, R. (2019, April 26). The vertical mosaic. The Canadian Encyclopedia. https://www.thecanadianencyclopedia.ca/en/ article/vertical-mosaic

Huff, R. (2014, November 26). Organizational culture. Britannica. https:// www.britannica.com/topic/organizational-culture

Inwood, G. J. (1999). Understanding Canadian public administration: An introduction to theory and practice. Prentice Hall.

Jain, H. C., Singh, P., \& Agocs, C. (2000). Recruitment, selection and promotion of visible-minority and Aboriginal police officers in selected Canadian police services. Canadian Public Administration, 43(1), 46-74.

Mall, R. (2017, April 26). Peel Regional Police discriminated against staff sergeant Baliiwan Sandhu on the basis of his race. https:// voiceonline.com/regional-discriminated-baljiwan/

Ministry of the Solicitor General. (2019, November 27). Policing in Ontario. https://www.mcscs.jus.gov.on.ca/english/police_serv/ about.html

Niemi, F. (2004, December). Systemic barriers to racially representative law enforcement agencies. Ontario Human Rights Commission. https://www.ohrc.on.ca/en/race-policy-dialogue-papers/systemicbarriers-racially-representative-law-enforcement-agencies

Oliver, P. (2017, March 8). Creating a multicultural law enforcement agency: An intentional priority. Police Chief Magazine. https://www. policechiefmagazine.org/creating-a-multicultural-law-enforcementagency/

Ontario Association of Chiefs of Police. (2020). Ontario police organizations. https://www.oacp.ca/en/about-us/ontario-policeorganizations.aspx

Ontario Human Rights Commission. (n.d.). Racism and racial discrimination: Systemic discrimination. http://www.ohrc.on.ca/en/racism-andracial-discrimination-systemic-discrimination-fact-sheet

Ottawa Police Service. (2021). Chief Peter Sloly. https://www. ottawapolice.ca/en/about-us/chief-peter-sloly.aspx

Rigaux, C. (2018, February). Challenges in a Western Canadian police force to the recruitment and retention of police cadets from four visible minority groups - South Asian, Chinese, Filipino and Black. http://dspace.library.uvic.ca/bitstream/handle/1828/9703/ Rigaux_Catherine_MPA_2018.pdf? sequence=1\&isAllowed =y

Sloly, P. (2020, July 24). Systemic racism in policing in Canada. https:// www.cacp.ca/index.htmleasst_id $=2208$

Statistics Canada. (2019a, June 18). Census profile, 2016 census - Surrey, city [Census subdivision], British Columbia and British Columbia [Province]. https://wwwl2.statcan.gc.ca/censusrecensement/2016/dp-pd/prof/details/page.cfm? Lang =E\& Geol $=$ CSD \&Codel $=5915004 \&$ Geo2 $=$ PR \&Code $2=59 \&$ Data $=$ Count $\&$ SearchText $=$ Vancouver $\&$ SearchType $=$ Begins $\&$ Search $\mathrm{PR}=01 \& \mathrm{~B} 1=\mathrm{All}$

Statistics Canada. (2019b, October 3). Police personnel and expenditures in Canada, 2018. https://www150.statcan.gc.ca/nl/pub/11-627m/11-627-m2019060-eng.htm

Stewart, N., \& Azpiri, J. (2020, November 25). "The fix was in": Hiring process for Surrey municipal police chief raises concerns. Global News. https://globalnews.ca/news/7483601/surrey-municipalpolice-chief-hiring-process-concerns/ 
Szeto, J. K. (2014). Policing diversity with diversity: Exploring organizational rhetoric, myth, and minority police officers' perceptions and experiences. Theses and Dissertations (Comprehensive). https:// scholars.wlu.ca/cgi/viewcontent.cgie article $=2762 \&$ context=etd
Yogaretnam, S. (2018, March 29). Exclusive: Senior Ottawa officer alleges racism, discrimination by police chief in human rights complaint. Ottawa Citizen. https://ottawacitizen.com/news/localnews/exclusive-senior-ottawa-officer-alleges-racism-discrimination-bypolice-chief-in-human-rights-complaint 